\title{
ANALISIS KESULITAN BELAJAR SISWA DALAM MENYELESAIKAN SOAL-SOAL JURNAL PENYESUAIAN PADA MATA PELAJARAN AKUNTANSI DI SMK SETIA DARMA PALEMBANG
}

\author{
Oleh : Irena \\ (PT. INDOMARINE JAYA SAKTI)
}

irenarena04@gmail.com

\begin{abstract}
Abstrak-Tujuan penelitian ini adalah untuk mengetahui kesulitan belajar yang dialami siswa dalam menyelesaikan soal-soal jurnal penyesuaian pada mata pelajaran akuntansi di SMK Setia Darma Palembang. Metode penelitian yang digunakan dalam penelitian ini adalah metode deskriptif pendekatan kuantitatif. Populasi dalam penelitian ini berjumlah 101 siswa. Sampel dalam penelitian ini berjumlah 38 siswa. Teknik pengumpulan data yang digunakan dalam penelitian ini yaitu tes dan angket. Hasil penelitian menunjukkan bahwa 83,96\% siswa mengalami kesulitan dalam menjurnal dan 16,04\% siswa mengalami kesulitan dalam menghitung. Sedangkan berdasarkan hasil keseluruhan nilai siswa dalam menyelesaikan soal jurnal penyesuaian diketahui nilai persentase tertinggi adalah 29,68\% dalam kategori "cukup" sebanyak 19 siswa, persentase 9,37\% sebanyak 6 siswa dengan kategori "kurang" dan sebanyak 13 siswa dalam kategori "kurang sekali" dengan persentase sebesar 20,31\%. Sedangkan untuk hasil angket diketahui bahwa 24,59\% disebabkan oleh faktor intern meliputi faktor anak didik itu sendiri sedangkan 75,40\% disebabkan oleh faktor ekstern meliputi faktor sekolah, keluarga dan masyarakat sekitar.
\end{abstract}

Kata Kunci : Kesulitan Belajar, Jurnal Penyesuaian.

\begin{abstract}
The purpose of this study was to determine the learning difficulties experienced by students in solving adjusting journal questions on accounting subjects at SMK Setia Darma Palembang. The research method used in this research is descriptive quantitative approach method. The population in this study amounted to 101 students. The sample in this study amounted to 38 students. Data collection techniques used in this study are tests and questionnaires. The results showed that $83.96 \%$ of students had difficulty in journaling and $16.04 \%$ of students had difficulty in counting. While based on the overall results of the students' scores in completing the adjusting journal questions it is known that the highest percentage score is $29.68 \%$ in the "enough" category of 19 students, the percentage of $9.37 \%$ for 6 students in the "less" category and as many as 13 students in the "less" category once "with a percentage of $20.31 \%$. As for the questionnaire results, it is known that $24.59 \%$ is caused by internal factors including the students themselves while $75.40 \%$ is caused by external factors including the factors of schools, families and surrounding communities.
\end{abstract}

Keywords: Learning Difficulties, Adjustment Journal 


\section{PENDAHULUAN}

Belajar merupakan proses dasar dari perkembangan hidup manusia. Belajar merupakan suatu usaha atau kegiatan yang bertujuan mengadakan perubahan didalam diri seseorang, yaitu perubahan tingkah laku, sikap, dan kebiasaan, ilmu pengetahuan, keterampilan dan sebagainya.

Dalam keseluruhan proses pendidikan di sekolah, kegiatan belajar merupakan kegiatan yang paling pokok. Sekolah sebagai sarana pendidikan formal yang merupakan tempat berlangsungnya proses belajar mengajar harus dapat memberikan ilmu yang bermanfaat bagi dunia pendidikan. Aktivitas belajar bagi setiap individu, tidak selamanya dapat berlangsung secara wajar. Kadang-kadang lancar, kadang-kadang tidak, kadang-kadang dapat cepat menangkap apa yang dipelajari, kadang-kadang terasa amat sulit.Perbedaan individual ini pulalah yang menyebabkan perbedaan tingkah laku belajar dikalangan anak didik.

Dalam keadaan di mana anak didik/siswa tidak dapat belajar sebagaimana mestinya, itulah yang disebut dengan "kesulitan belajar" (Abu danWidodo, 2013:77). Secara umum, kesulitan belajar merupakan suatu kondisi proses belajar yang ditandai oleh hambatan-hambatan tertentu untuk mencapai kesuksesan.

Dalam belajar ilmu akuntansi memang tidak bisa dipahami secara langsung, namun harus bertahap sesuai dengan prosedur akuntansi yang telah ada yang dimulai dari persamaan dasar akuntansi, jurnal umum, buku besar, neraca saldo, jurnal penyesuaian, kertas kerja, laporan keuangan hingga jurnal penutup dan jurnal pembalik. Untuk mencapai itu semua tentu tidak sedikit siswa yang mengalami beberapa kesulitan dalam mempelajarinya yang disebabkan oleh beberapa faktor tertentu.

Kesulitan dalam belajar dapat disebabkan oleh berbagai faktor diantaranya datang dari dalam diri siswa itu sendiri seperti kesulitan dalam memahami bahasa lisan dan tulisan, mendengarkan, berfikir, membaca, menulis, dan berhitung. Hal ini terjadi karena adanya faktor lain seperti pengaruh lingkungan dan pembelajaran yang tidak efektif. Rendahnya hasil belajar yang dicapai oleh siswa karena kurangnya pemahaman terhadap materi jurnal penyesuaian dan kamampuan menalar dalam menganalisis transaksi sehingga menyebabkan kesalahan pencatatan. Kesalahan yang sering dilakukan oleh siswa yaitu menentukan jenis akun yang memerlukan penyesuaian. Nilai-nilai yang rendah (dibawah KKM) yang dicapai siswa inilah yang dapat dijadikan indikator tentang adanya kesulitan belajar yang dihadapi siswa.

Berdasarkan latar belakang yang telah dijelaskan diatas maka 
Penelitimengadakan penelitian dengan judul "Analisis Kesulitan Belajar Siswa dalam Menyelesaikan Soal-soal Jurnal Penyesuaian Pada Mata Pelajaran Akuntansi Kelas X di SMK Setia Darma Palembang Tahun Pelajaran 2016/2017". Adapun tujuan yang hendak dicapai dalam penelitian ini adalah untuk mengetahui kesulitan belajar siswa dalam menyelesaikan soal-soal jurnal penyesuaian pada mata pelajaran akuntansi di SMK Setia Darma Palembang Tahun Pelajaran 2016/2017.

\section{METODE PENELITIAN}

"Variabel penelitian adalah segala sesuatu yang berbentuk apa saja yang ditetapkan oleh peneliti untuk dipelajari sehingga diperoleh informasi tentang hal tersebut, kemudian ditarik kesimpulannya" (Sugiyono, 2015:60), yang menjadi variabel dalam penelitian ini adalah "kesulitan belajar siswa".

Populasi dalam penelitian ini adalah seluruh siswa kelas $X$ jurusan akuntansi di SMK Setia Darma Palembang yang berjumlah 101 siswa. Untuk memperoleh sampel penelitian, terlebih dahulu dilakukan tes kepada siswa untuk mengetahui jumlah siswa yang mengalami kesulitan belajar. ketiga kelas populasi dianggap relatif homogen karena penempatan siswa pada tiap kelas telah diacak oleh guru. Jumlah siswa yang dilakukan tes awal untuk mendapatkan sampel diambil 2 kelas yaitu kelas $\mathrm{X}$ AK 2 dan $\mathrm{X}$ AK3, karena kelas $\mathrm{X}$ AK 1 digunakan untuk uji validitas. Berdasarkan tes yang telah diberikan kepada siswa diketahui bahwa nilai siswa yang memperoleh nilai diatas Kriteria Ketuntasan Minimal (KKM) mata pelajaran akuntansi sebesar 75 .

Metode penelitian deskriptif dengan pendekatan kuantitatif dalam penelitian ini bertujuan untuk mengetahui penyebab kesulitan belajar siswa kelas $\mathrm{X}$ dalam menyelesaikan jurnal penyesuaian pada mata pelajaran akuntansi di SMK Setia Darma Palembang tahun pelajaran 2016/2017.

Adapun teknik pengumpulan data dalam penelitian dengan menggunakan tes dan angket.

"Tes adalah serentetan pertanyaan atau latihan serta alat lain yang digunakan untuk mengukur keterampilan, pengetahuan intelegensi, kemampuan atau bakat yang dimiliki oleh individu atau kelompok" (Arikunto, 2013:193). Tes dalam penelitian ini digunakan untuk mengetahui kesulitan belajar siswa dalam menyelesaikan soal-soal jurnal penyesuaian pada perusahaan dagang.

"Angket adalah sejumlah pertanyaan tertulis yang digunakan untuk memperoleh informasi dari responden dalam arti laporan tentang pribadinya, atau hal-hal yang ia ketahui" (Arikunto, 2013:194). Angket digunakan untuk mengetahui 
penyebab kesulitan belajar siswa dalam menyelesaiakan jurnal penyesuiaan. Angket dalam penelitian ini adalah angket tertutup yang mana sudah disediakan jawabannya sehingga responden tinggal memilih jawaban yang telah disediakan. Angket berjumlah 46 pertanyaan dengan 4 alternatif jawaban sebagai berikut:
a) selalu
c) kadang
b) sering
d) tidak pernah

\section{HASIL DAN PEMBAHASAN}

SMK Setia Darma Palembang yang terletak di Jalan D.I Panjaitan Lr. Pasundan Kecamatan Plaju Darat. Sekolah ini berdiri pada tahun 1994.Dahulu nama sekolah yaitu SMK YPGR (Yasasan Perguruan Gotong Royong) yang kemudian berganti nama menjadi SMK Setia Darma Palembang sejak tahun 2005. SMK Setia Darma Palembang ini sudah cukup banyak dikenal dan diminati oleh masyarakat, hal ini terbukti dari banyaknya siswa yang berasal dari berbagai daerah. Karena sekolah ini merupakan satu-satunya Sekolah Menengah kejuruan (SMK) yang terdapat di Kecamatan Plaju Darat.

Penelitian ini dilakukan di SMK Setia Darma Palembang yang berlokasi di Jalan D.I Panjaitan Lr. Pasundan Kecamatan Plaju Darat, dengan jumlah siswa yang menjadi sampel sebanyak 38 siswa kelas $\mathrm{X}$ Akuntansi 1 dan X Akuntansi 2. Penelitian ini dilaksanakan pada tanggal 15 Mei 2017 sampai dengan 20 Juli 2017 untuk mengetahui kesulitan siswa dalam menyelesaikan soal jurnal penyesuaian di SMK Setia Darma Palembang melalui pemberian tes.

Berdasarkan nilai hasil tes siswa materi ayat jurnal penyesuaian diketahui bahwa, siswa yang mencapai nilai (86-100\%) sebanyak 13 orang siswa dengan kategori "Sangat Baik",dan pada kategori "Baik" terdapat 13 orang siswa yang mencapai nilai (76-85\%), kemudian siswa yang mencapai nilai $(60-75 \%)$ sebanyak 19 orang siswa dengan kategori "Cukup", sedangkan pada kategori "Kurang" siswa yang mencapai nilai $(55-59 \%)$ terdapat 6 orang siswa, lalu siswa yang mencapai nilai $(\leq 54 \%$ ) sebanyak 13 orang siswa dengan kategori "Kurang Sekali". Setelah dilakukan tes kepada setiap siswa maka diperoleh nilai dari masing-masing siswa, dan dapat diketahui siswa yang menjadi sampel. Berdasarkan data hasil analisis angket yang diberikan kepada 38 siswa yang mengalami kesulitan belajar dideskriptif persentasenya sebagai berikut:

1. Pada angket nomor 1 pada faktor intern yang meliputi faktor anak didik dengan pertanyaan "Pernahkah Anda berpikir bahwa Anda adalah seorang yang mempunyai intelegensi rendah atau dibawah rata-rata?" dilihat dari persentase jawaban 
siswa sebesar $\quad 15,78 \%$ menyatakan "Selalu", $18,42 \%$ menyatakan "Sering", 39,48\% menyatakan "Kadang-kadang", dan $26,32 \%$ menyatakan "Tidak Pernah".

2. Pada angket nomor 4 pada faktor intern yang meliputi faktor anak didik dengan pertanyaan "Saya berpikir bahwa saya mempunyai bakat dalam menguasai pelajaran akuntansi" dilihat dari persentase jawaban siswa sebesar $15,78 \%$ menyatakan "Selalu", 10,53\% menyatakan "Sering", 23,69\% menyatakan "Kadang-kadang" dan 50,00\% menyatakan tidak pernah.

3. Pada angket nomor 8 pada faktor intern yang meliputi faktor anak didik dengan pertanyaan "Saya merasa tidak ada minat untuk belajar materi ayat jurnal penyesuaian" dilihat dari persentase jawaban siswa sebesar $31,57 \%$ menyatakan "Selalu, 23,69\% menyatakan "Sering", 21,05\% menyatakan "Kadang-kadang", dan 23,69\% menyatakan "Tidak Pernah".

4. Pada angket nomor 11 pada faktor intern yang meliputi faktor anak didik dengan pertanyaan "Saya kurang termotivasi belajar materi ayat jurnal penyesuaian" dilihat dari persentase jawaban siswa sebesar 23,69\% menyatakan "Selalu, 39,48\% menyatakan "Sering", 13,15\% menyatakan
"Kadang-kadang", dan 23,69\% menyatakan "Tidak Pernah".

5. Pada angket nomor 15 pada faktor intern yang meliputi faktor anak didik dengan pertanyaan "Saya selalu bingung saat menghadapi masalah dalam mengerjakan soal ayat jurnal penyesuaian" dilihat dari persentase jawaban siswa sebesar 23,69\% menyatakan "Selalu, 28,94\% menyatakan "Sering", 23,69\% menyatakan "Kadang-kadang", dan 23,69\% menyatakan "Tidak Pernah".

6. Pada angket nomor 21 pada faktor intern yang meliputi faktor anak didik dengan pertanyaan "Saya malas-malasan belajar saat berada dirumah dan lebih memilih menonton TV" dilihat dari persentase jawaban siswa sebesar $18,42 \%$ menyatakan "Selalu, 21,05\% menyatakan "Sering", 34,21\% menyatakan "Kadang-kadang", dan $26,32 \%$ menyatakan "Tidak Pernah".

7. Pada angket nomor 21 pada faktor intern yang meliputi faktor anak didik dengan pertanyaan "Saya malas-malasan belajar saat berada dirumah dan lebih memilih menonton TV" dilihat dari persentase jawaban siswa sebesar $18,42 \%$ menyatakan "Selalu, 21,05\% menyatakan "Sering", 34,21\% menyatakan "Kadang-kadang", 
dan $26,32 \%$ menyatakan "Tidak Pernah".

8. Pada angket nomor 29 pada faktor intern yang meliputi faktor anak didik dengan pertanyaan "Saya mempunyai latar belakang yang pahit sewaktu kecil (trauma), sehingga sulit untuk memahami pelajaran dengan mudah" dilihat dari persentase jawaban siswa sebesar 21,05\% menyatakan "Selalu, 28,94\% menyatakan "Sering", 26,32\% menyatakan "Kadang-kadang", dan 23,69\% menyatakan "Tidak Pernah".

9. Pada angket nomor 23 pada faktor intern yang meliputi faktor anak didik dengan pertanyaan "Pendengaran dan penglihatan saya terganggu saat guru menjelaskan materi pelajaran akuntansi" dilihat dari persentase jawaban siswa sebesar $18,42 \%$ menyatakan "Selalu, 26,32\% menyatakan "Sering", 31,57\% menyatakan "Kadang-kadang", dan 23,69\% menyatakan "Tidak Pernah".

10. Pada angket nomor 34 pada faktor intern yang meliputi faktor anak didik dengan pertanyaan "Saya merasa tidak memahami materi ayat jurnal penyesuaian apabila saya sedang mengantuk atau keadaan fisik yang kurang baik" dilihat dari persentase jawaban siswa sebesar 42,11\% menyatakan "Selalu, 26,32\% menyatakan
"Sering", 13,15\% menyatakan "Kadang-kadang", dan 18,42\% menyatakan "Tidak Pernah".

11. Pada angket nomor 35 pada faktor intern yang meliputi faktor anak didik dengan pertanyaan "Saya merasa mempunyai kemampuan atau keterampilan dasar dalam bidang akuntansi sehingga saya mempunyai bekal untuk kedepannya nanti" dilihat dari persentase jawaban siswa sebesar 21,05\% menyatakan "Selalu, 23,69\% menyatakan "Sering", 31,57\% menyatakan "Kadang-kadang", dan 23,69\% menyatakan "Tidak Pernah".

12. Pada angket nomor 37 pada faktor intern yang meliputi faktor anak didik dengan pertanyaan "Saya dapat memahami materi ayat jurnal penyesuaian yang dijelaskan oleh guru dengan metode ceramah " dilihat dari persentase jawaban siswa sebesar 26,32\%\% menyatakan "Selalu, 26,32\% menyatakan "Sering", 31,57\% menyatakan "Kadang-kadang", dan $15,78 \%$ menyatakan "Tidak Pernah".

13. Pada angket nomor 2 pada faktor ekstern yang meliputi faktor sekolah dengan pertanyaan "Apakah guru menggunakan bahasa yang kurang santun saat mengajar?" dilihat dari persentase jawaban siswa sebesar $18,42 \%$ menyatakan 
"Selalu, $18,42 \%$ menyatakan "Sering", 26,32\% menyatakan "Kadang-kadang", dan 36,84\% menyatakan "Tidak Pernah".

14. Pada angket nomor 5 pada faktor ekstern yang meliputi faktor sekolahdengan pertanyaan "Apakah saat mengajar guru kurang menguasai materi pelajaran akuntansi yang diajarkan?" dilihat dari persentase jawaban siswa sebesar $18,42 \%$ menyatakan "Selalu, $13,15 \%$ menyatakan "Sering", 44,74\% menyatakan "Kadang-kadang", dan 23,69\% menyatakan "Tidak Pernah".

15. Pada angket nomor 7 pada faktor ekstern yang meliputi faktor sekolahdengan pertanyaan "Saya dibantu oleh guru jika saya kesulitan dalam mengerjakan soal ayat jurnal penyesuaian" dilihat dari persentase jawaban siswa sebesar 26,32\% menyatakan "Selalu, 23,69\% menyatakan "Sering", 39,48\% menyatakan "Kadang-kadang", dan 10,53\% menyatakan "Tidak Pernah".

16. Pada angket nomor 10 pada faktor ekstern yang meliputi faktor sekolahdengan pertanyaan "Apakah guru Anda menuntut standar pelajaran diatas kemampuan Anda?" dilihat dari persentase jawaban siswa sebesar $21,05 \%$ menyatakan "Selalu, 34,21\% menyatakan "Sering", 26,32\% menyatakan
"Kadang-kadang", dan 18,42\% menyatakan "Tidak Pernah".

17. Pada angket nomor 13 pada faktor ekstern yang meliputi faktor sekolahdengan pertanyaan "Jika guru menyampaikan materi ayat jurnal penyesuaian dengan tidak jelas, maka saya tidak berminat untuk mengikuti pelajaran akuntansi" dilihat dari persentase jawaban siswa sebesar $18,42 \%$ menyatakan "Selalu, 31,57\% menyatakan "Sering", 26,32\% menyatakan "Kadang-kadang", dan 23,69\% menyatakan "Tidak Pernah".

18. Pada angket nomor 16 pada faktor ekstern yang meliputi faktor sekolah dengan pertanyaan "Apakah Anda mengikuti kegiatan organisasi masyarakat dalam lingkungan rumah Anda?" dilihat dari persentase jawaban siswa sebesar $18,42 \%$ menyatakan "Selalu, 15,78\% menyatakan "Sering", 39,48\% menyatakan "Kadang-kadang", dan 26,32\% menyatakan "Tidak Pernah".

19. Pada angket nomor 22 pada faktor ekstern yang meliputi faktor sekolah dengan pertanyaan "Apakah guru hanya menggunakan satu metode saja saat mengajar dan tidak bervariasi?" dilihat dari persentase jawaban siswa sebesar $18,42 \%$ menyatakan "Selalu, 39,48\% menyatakan "Sering", 21,05\% menyatakan 
"Kadang-kadang", dan 21,05\% menyatakan "Tidak Pernah".

20. Pada angket nomor 25 pada faktor ekstern yang meliputi faktor sekolah dengan pertanyaan "Saya merasa alat atau media pembelajaran disekolah kurang baik, sehingga dapat menghambat kelancaran belajar akuntansi" dilihat dari persentase jawaban siswa sebesar 26,32\% menyatakan "Selalu, 44,74\% menyatakan "Sering", $15,78 \%$ menyatakan "Kadang-kadang", dan 13,15\% menyatakan "Tidak Pernah".

21. Pada angket nomor 26 pada faktor ekstern yang meliputi faktor sekolah dengan pertanyaan "Saya kekurangan buku pelajaran akuntansi karena perpustakaan yang disediakan sekolah kurang memadai" dilihat dari persentase jawaban siswa sebesar $39,48 \%$ menyatakan "Selalu, 26,32\% menyatakan "Sering", 23,69\% menyatakan "Kadang-kadang", dan 10,53\% menyatakan "Tidak Pernah".

22. Pada angket nomor 28 pada faktor ekstern yang meliputi faktor sekolah dengan pertanyaan "Saya berkesulitan belajar karena pergantian kurikulum yang baru, sehingga bahan-bahan pelajarannya terlalu tinggi/sulit dimengerti" dilihat dari persentase jawaban siswa sebesar $23,69 \%$ menyatakan "Selalu, 23,69\% menyatakan "Sering", 34,21\% menyatakan "Kadang-kadang", dan $18,42 \%$ menyatakan "Tidak Pernah".

23. Pada angket nomor 33 pada faktor ekstern yang meliputi faktor sekolah dengan pertanyaan "Saya berkesulitan belajar karena pergantian kurikulum yang baru, sehingga bahan-bahan pelajarannya terlalu tinggi/sulit dimengerti" dilihat dari persentase jawaban siswa sebesar $34,21 \%$ menyatakan "Selalu, 28,94\% menyatakan "Sering", 23,69\% menyatakan "Kadang-kadang", dan $13,15 \%$ menyatakan "Tidak Pernah".

24. Pada angket nomor 36 pada faktor ekstern yang meliputi faktor sekolah dengan pertanyaan "Saya tidak dapat belajar dengan konsentrasi, karena letak gedung sekolah yang dekat dengan jalan raya dan pabrik karet" dilihat dari persentase jawaban siswa sebesar 23,69\% menyatakan "Selalu, 23,69\% menyatakan "Sering", 31,57\% menyatakan "Kadang-kadang", dan 21,05\% menyatakan "Tidak Pernah".

25. Pada angket nomor 39 pada faktor ekstern yang meliputi faktor sekolah dengan pertanyaan "Apabila Anda mempunyai masalah seperti: kesulitan belajar, perselisihan dengan teman sekelas, dan tidak 
mengerjakan tugas yang diberikan oleh guru, apakah Anda mendapatkan bimbingan dan arahan dari guru BK disekolah untuk mendapatkan solusinya?" dilihat dari persentase jawaban siswa sebesar 39,48\% menyatakan "Selalu, 26,32\% menyatakan "Sering", 23,69\% menyatakan "Kadang-kadang", dan 10,53\% menyatakan "Tidak Pernah".

26. Pada angket nomor 38 pada faktor ekstern yang meliputi faktor sekolah dengan pertanyaan "Apakah Anda kurang puas dengan pelayanan administrasi yang diberikan sekolah?" dilihat dari persentase jawaban siswa sebesar 13,15\% menyatakan "Selalu, $18,42 \%$ menyatakan "Sering", 23,69\% menyatakan "Kadang-kadang", dan $44,74 \%$ menyatakan "Tidak Pernah".

27. Pada angket nomor 3 pada faktor ekstern yang meliputi faktor keluarga dengan pertanyaan "Orang tua saya terlalu sibuk dengan pekerjaannya sendiri, sehingga saya kurang diperhatikan oleh orang tua saya saat berada dirumah" dilihat dari persentase jawaban siswa sebesar 28,94\% menyatakan "Selalu, 34,21\% menyatakan "Sering", 23,69\% menyatakan "Kadang-kadang", dan 13,15\% menyatakan "Tidak Pernah".
28. Pada angket nomor 6 pada faktor ekstern yang meliputi faktor keluarga dengan pertanyaan "Kedua orang tua saya acuh saat berada dirumah" dilihat dari persentase jawaban siswa sebesar 23,69\% menyatakan "Selalu, 26,32\% menyatakan "Sering", 31,57\% menyatakan "Kadang-kadang", dan 18,42\% menyatakan "Tidak Pernah"

29. Pada angket nomor 14 pada faktor ekstern yang meliputi faktor keluarga dengan pertanyaan "Orang tua saya mengeluh karena kurangnya biaya pendidikan yang disediakan untuk saya" dilihat dari persentase jawaban siswa sebesar 21,05\% menyatakan "Selalu, 23,69\% menyatakan "Sering", 15,78\% menyatakan "Kadang-kadang", dan 39,48\% menyatakan "Tidak Pernah"

30. Pada angket nomor 19 pada faktor ekstern yang meliputi faktor keluarga dengan pertanyaan "Saat belajar dirumah saya selalu belajar diruangan khusus yang disediakan oleh orang tua" dilihat dari persentase jawaban siswa sebesar $23,69 \%$ menyatakan "Selalu, 21,05\% menyatakan "Sering", 26,32\% menyatakan "Kadang-kadang", dan 28,94\% menyatakan "Tidak Pernah"

31. Pada angket nomor 24 pada faktor ekstern yang meliputi 
faktor keluarga dengan pertanyaan "Saya merasakan perekonomian keluarga saya sedang sulit, sehingga menggangu aktivitas belajar saya" dilihat dari persentase jawaban siswa sebesar 26,32\% menyatakan "Selalu, 28,94\% menyatakan "Sering", 23,69\% menyatakan "Kadang-kadang", dan 21,05\% menyatakan "Tidak Pernah"

32. Pada angket nomor 27 pada faktor ekstern yang meliputi faktor keluarga dengan pertanyaan "Jika orang tua atau saudara saya sedang sakit. Saya merasa tidak berkonsentrasi dalam belajar karena menjadi beban pikiran saya" dilihat dari persentase jawaban siswa sebesar 26,32\% menyatakan "Selalu, 26,32\% menyatakan "Sering", 26,32\% menyatakan "Kadang-kadang", dan 21,05\% menyatakan "Tidak Pernah"

33. Pada angket nomor 30 pada faktor ekstern yang meliputi faktor keluarga dengan pertanyaan "Saya tidak merasa bosan pada saat belajar disekolah dan mengerjakan tugas-tugas (PR) yang diberikan oleh guru" dilihat dari persentase jawaban siswa sebesar 26,32\% menyatakan "Selalu, 23,69\% menyatakan "Sering", 28,94\% menyatakan "Kadang-kadang", dan 21,05\% menyatakan "Tidak Pernah"
34. Pada angket nomor 31 pada faktor ekstern yang meliputi faktor keluarga dengan pertanyaan "Apakah Anda diperlakukan tidak adil/pilih kasih oleh orang tua Anda dibandingkan dengan saudara kandung Anda yang lainnya?" dilihat dari persentase jawaban siswa sebesar $21,05 \%$ menyatakan "Selalu, $18,42 \%$ menyatakan "Sering", 26,32\% menyatakan "Kadang-kadang", dan 34,21\% menyatakan "Tidak Pernah"

35. Pada angket nomor 32 pada faktor ekstern yang meliputi faktor keluarga dengan pertanyaan "Sepulang sekolah saya membantu pekerjaan orang tua saya dirumah" dilihat dari persentase jawaban siswa sebesar $23,69 \%$ menyatakan "Selalu, 26,32\% menyatakan "Sering", 28,94\% menyatakan "Kadang-kadang", dan 21,05\% menyatakan "Tidak Pernah"

36. Pada angket nomor 12 pada faktor ekstern yang meliputi faktor masyarakat dengan pertanyaan "Saya akan tetap bergaul (berteman) disekitar tempat tinggal saya walaupun diantara mereka ada yang putus sekolah (tidak sekolah)" dilihat dari persentase jawaban siswa sebesar 23,69\% menyatakan "Selalu, 36,84\% menyatakan "Sering", 21,05\% menyatakan 
"Kadang-kadang", dan 18,42\% menyatakan "Tidak Pernah"

37. Pada angket nomor 17 pada faktor ekstern yang meliputi faktor masyarakat dengan pertanyaan "Apakah Anda sering melihat disekitar lingkungan rumah Anda terdapat orang-orang berkelakuan tidak baik seperti mabuk-mabukan dan berjudi?" dilihat dari persentase jawaban siswa sebesar 26,32\% menyatakan "Selalu, 31,57\% menyatakan "Sering", $18,42 \%$ menyatakan "Kadang-kadang", dan 23,69\% menyatakan "Tidak Pernah"

38. Pada angket nomor 18 pada faktor ekstern yang meliputi faktor masyarakat dengan pertanyaan "Apakah Anda mengikuti kegiatan organisasi masyarakat dalam lingkungan rumah Anda?" dilihat dari persentase jawaban siswa sebesar $18,42 \%$ menyatakan "Selalu, 18,42\% menyatakan "Sering", 23,69\% menyatakan "Kadang-kadang", dan 39,48\% menyatakan "Tidak Pernah"

39. Pada angket nomor 20 pada faktor ekstern yang meliputi faktor masyarakat dengan pertanyaan "Disekitar rumah saya sering terjadi keributan dan perkelahian antar sesama tetangga" dilihat dari persentase jawaban siswa sebesar 21,05\% menyatakan "Selalu, 18,42\% menyatakan "Sering", 26,32\% menyatakan "Kadang-kadang", dan 34,21\% menyatakan "Tidak Pernah"

\begin{tabular}{ccr}
\multicolumn{2}{c}{ Berdasarkan angket } & yang \\
disebarkan & pada & responden \\
selanjutnya & dianalisis & untuk \\
mengetahui & faktor & yang
\end{tabular}
menyebabkan kesulitan belajar siswa dalam menyelesaikan soal jurnal penyesuaian pada mata pelajaran akuntansi siswa kelas $\mathrm{X}$ di SMK Setia Darma Palembang. Kesulitan yang dimaksud terdiri dari dua indikator faktor intern berjumlah 11 item pertanyaan dan faktor ekstern berjumlah 28 item pertanyaan. Berdasarkan hasil angket tersebut dapat dilihat analisisnya pada gambar berikut: 
Gambar 1. Hasil Angket Siswa Pada Faktor Intern Dan Ekstern

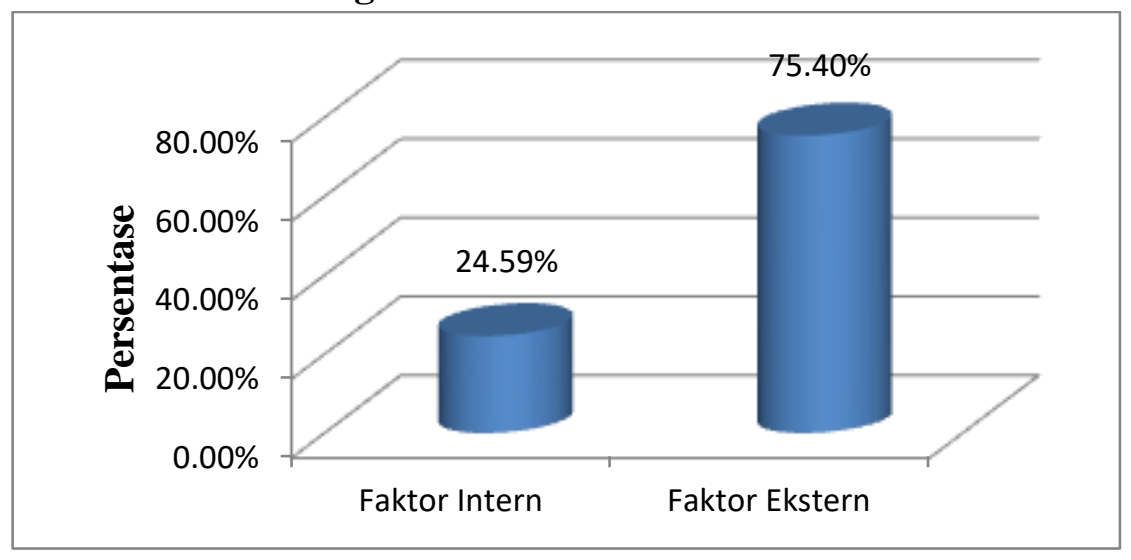

Dari hasil diagram di atas, dapat diketahui bahwa persentase faktor yang menyebabkan kesulitan belajar siswa pada faktor intern dalam jurnal penyesuaian pada siswa kelas X di SMK Setia Darma Palembang sebesar 24,59\% dengan jumlah 11 item pertanyaan sedangkan faktor ekstern sebesar $75,40 \%$ dengan jumlah 28 item pertanyaan. Dari hasil tersebut diketahui bahwa persentase tertinggi faktor yang menyebabkan kesulitan belajar siswa yaitu berasal dari faktor ekstern yang disebabkan oleh faktor sekolah.

Penelitian ini dilaksanakan di SMK Setia Darma Palembang yang berada di Jalan D.I Panjaitan Lr. Pasundan Kecamatan Plaju Darat Palembang. Berdasarkan data yang diperoleh peneliti kesekolah populasi dalam penelitian ini sebanyak 101 orang siswa kelas $\mathrm{X}$ akuntansi tahun pelajaran 2016/2017. Sebelum pengambilan sampel terlebih dahulu diadakan tes tertulis berupa soal pilihan ganda sebanyak 21 soal dengan 4 alternatif jawaban materi ayat jurnal penyesuaian yang terdiri dari mengenai akun perlengkapan, beban dibayar dimuka, penyusutan aktiva, beban yang masih harus dibayar, pendapatan yang masih harus diterima, pendapatan diterima dimuka, piutang tak tertagih, persediaan barang dagang, dan koreksi kesalahan.

Menurut Wahab (2015:191). Kesulitan belajar adalah suatu kondisi dimana anak didik tidak dapat belajar secara wajar, disebabkan adanya ancaman, hambatan ataupun gangguan belajar tertentu yang dialami siswa atau anak didik. Kesulitan belajar biasanya tampak jelas dari menurunnya kinerja akademik atau prestasi belajar yang dicapai siswa. Pendapat tersebut sesuai dengan hasil angket dimana diketahui bahwa kesulitan siswa dalam jurnal penyesuaian disebabkan oleh faktor intern dan ekstern. Faktor intern meliputi faktor dalam diri anak didik sedangkan faktor ekstern meliputi faktor 
sekolah, keluarga dan lingkungan masyarakat. Hal ini ditunjukkan oleh hasil jawaban angket faktor intern yaitu berasal dari faktor anak didik dengan rata-rata persentase sebesar $59,43 \%$ dan rata-rata keseluruhan persentase faktor internsebesar $24,59 \%$ dengan sedangkan pada faktor ekstern yaitu berasal dari faktor sekolah dengan rata-rata persentase sebesar $61,21 \%$, pada faktor keluarga sebesar $60,44 \%$, dan pada faktor masyarakat sekitar sebesar $60,57 \%$ dengan persentase rata-rata keseluruhan faktor ekstern sebesar $75,40 \%$.

\section{KESIMPULAN DAN SARAN}

Berdasarkan hasil penelitian mengenai analisis kesulitan belajar siswa dalam menyelesaikan soal jurnal penyesuaian pada mata pelajaran akuntansi kelas X di SMK Setia Darma Palembang tahun pelajaran 2016/2017, dapat disimpulkan sebagai berikut:

1) Hasil analisis tes siswa dalam menyelesaikan soal jurnal penyesuaian di SMK Setia Darma Palembang yaitu 83,96\% siswa mengalami kesulitan dalam menjurnal dan $16,04 \%$ siswa mengalami kesulitan dalam menghitung. sedangkan berdasarkan hasil keseluruhan siswa dalam menyelesaikan soal jurnal penyesuaian yang mengalami kesulitan belajar diketahui persentase rata-rata tertinggi sebesar $29,68 \%$ dengan kategori "cukup" sebanyak 19 siswa dengan nilai (60-75\%), yang memperoleh nilai (55$59 \%$ ) sebanyak 6 siswa dengan persentase rata-rata sebesar 9,37\% dalam kategori "kurang", dan dalam kategori "kurang sekali" sebanyak 13 siswa persentase rata-rata sebesar $20,31 \%$ dengan nilai $\leq 54 \%$.

2) Hasil analisis angket faktor yang menyebabkan kesulitan belajar siswa dalam menyelesaikan soal jurnal penyesuaian di SMK Setia Darma Palembang. Diketahui pada faktor intern disebabkan oleh faktor anak didik, berdasarkan rata-rata keseluruhan faktor intern yaitu sebesar $24,59 \%$ yang disebabkan oleh faktor anak didik itu sendiri, sedangkan faktor ekstern disebabkan oleh faktor sekolah,faktor keluarga dan faktor masyarakat sekitar dengan persentase rata-rata keseluruhan sebesar 75,40\%. Dari ketiga faktor ekstern tersebut yang paling dominan dipengaruhi oleh faktor sekolah dengan rata rata persentase sebesar $61,21 \%$. Pada Faktor sekolah dalam deskriptor "pribadi guru yang kurang baik" persentase sebesar 68,58\%, "Guru yang tidak berkualitas" persentase sebesar 66,66\%, "Hubungan guru dan murid yang kurang baik" persentase sebesar 64,74\%, "Guru menuntun standar pelajaran di atas 
kemampuan anak" persentase sebesar 60,89\%, "Guru tidak memiliki kecakapan dalam usaha kesulitan belajar anak" persentase sebesar 63,46\%, "Metode belajar yang tidak menarik" persentase sebesar $66,66 \%$," Guru hanya menggunakan satu metode" persentase sebesar 69,23\%, "Alat/media pembelajaran yang kurang memadai" persentase sebesar 52,56\%, "Perpustakaan yang kurang memadai" persentase sebesar 50,00\%, "Kondisi gedung sekolah yang tidak terpelihara dengan baik" persentase sebesar 60,25\%, "Kurikulum yang kurang baik, karena bahan pelajaran terlalu tinggi" persentase sebesar $52,56 \%$, "Suasana sekolah yang kurang menyenangkan" persentase sebesar 60,89\%, "Bimbingan dan pergaulan yang kurang berfungsi" persentase sebesar 71,79\%, "Kepemimpinan dan administrasi sekolah" persentase sebesar $48,71 \%$.

Dari beberapa kesimpulan di atas, maka peneliti memberikan saran sebagai berikut:

1) Bagi guru mata pelajaran akuntansi agar kemampuan siswa lebih baik lagi, hendaknya guru menggunakan metode pembelajaran yang bervariasi agar siswa tidak mengalami kejenuhan dalam belajar akuntansi, mengingat banyaknya jam mata pelajaran akuntansi yang diterima oleh guru.

2) Bagi sekolah diharapkan dari penelitian ini agar lebih melengkapi sarana prasarana sekolah dan lebih meningkatkan kedisiplinan sekolah

3) Bagi siswa hendaknya harus teliti lagi dalam mengerjakan soal jurnal penyesuaian serta lebih giat berlatih mengerjakan soal latihan serta memperhatikan penjelasan guru, apabila kurang jelas dalam pelajaran akuntansi atau mengalami masalah dalam belajar hendaknya siswa jangan takut untuk meminta bantuan kepada guru mata pelajaran akuntansi dan kepada guru Bimbingan Konseling (BK) agar mendapatkan arahan dan penyelesaian masalah dalam belajar.

4) Bagi peneliti selanjutnya perlu kiranya memperluas ruang lingkup penelitian dengan menganalisis transaksi dan melihat faktor intern yang berasal dari diri siswa maupun faktor ekstern yang berasal dari faktor sekolah, keluarga dan masyarakat sekitar.

\section{DAFTAR PUSTAKA}

Ahmadi Abu \& Supriyono Widodo. 2013. Psikologi Belajar. Jakarta: PT Rineka Cipta

Sugiyono. 2015. Metode Penelitian Pendidikan Pendekatan 
Kuantitatif, Kualitatif, dan

$R \& D$. Bandung: Alfabeta

Arikunto, Suharsimi 2013. Prosedur

Penelitian Suatu Pendekatan

Praktik. Jakarta: PT Rineka

Cipta

Wahab, Rohmalia. 2015. Psikologi

Belajar. Jakarta: PT

RajaGrafindo Persada 